\title{
Faktor-Faktor yang Mempengaruhi Pangsa Pasar Industri Keuangan Syariah Non-Bank
}

\author{
Diharpi Herli Setyowati, Ayu Sartika, Setiawan \\ Politeknik Negeri Bandung \\ Jl. Gegerkalong Hilir, Ds. Ciwaruga, Bandung 40012 \\ E-mail: diharpi.herli@polban.ac.id
}

Diterima: 2 November 2019; Direvisi: 18 Desember 2019; Diterbitkan: 20 Desember 2019

\begin{abstract}
Abstrak,
Pangsa pasar yang dapat dikuasai Industri Keuangan Syariah Non-Bank masih terbilang kecil, sehingga penelitian ini bertujuan untuk melihat adanya pengaruh Return on Assets (ROA), Return on Equity (ROE), Biaya Operasional Pendapatan Operasional (BOPO), dan Inflasi terhadap Pangsa Pasar Industri Keuangan Syariah Non-Bank. Data yang digunakan adalah data sekunder yang merupakan penggabungan antara data time series dan cross section, sehingga menjadi data panel. Populasi dalam penelitian ini adalah IKNB Syariah di Indonesia yang terdaftar di Otoritas Jasa Keuangan sebanyak lima sektor, sedangkan sampel penelitian ini yaitu tiga sektor Industri Keuangan Non-Bank Syariah yang tersedia laporan keuangan bulanannya. Metode analisis data penelitian ini menggunakan analisis regresi linear berganda dengan program SPSS versi 18. Beradasarkan hasil pengujian, data yang digunakan terdistribusi normal dan memenuhi seluruh kriteria uji asumsi klasik. Hasil penelitian ini juga menunjukkan bahwa terdapat pengaruh negatif dari ROA dan BOPO terhadap pangsa pasar, sedangkan ROE memiliki pengaruh positif terhadap pangsa pasar. Variabel Inflasi tidak memiliki pengaruh terhadap pangsa pasar. Kontribusi keseluruhan variabel independen terhadap variabel dependen yaitu Pangsa Pasar adalah sebesar 67\%, sedangkan sisanya ditentukan oleh variabel lain yang tidak diteliti dalam penelitian ini.
\end{abstract}

Kata Kunci: ROA, ROE, BOPO, Inflasi, Pangsa Pasar, Industri Keuangan Syariah Non-Bank

\begin{abstract}
,
The market share that can be controlled by the Non-Bank Financial Industry is still small, so this study aims to see the influence of Return on Assets (ROA), Return on Equity (ROE), Operational Income Operating Costs (BOPO), and Inflation on Market Share Islamic NonBank Financial Industry. The data used is secondary data which is a combination of time series data and cross section, so that it becomes panel data. The population in this study is the Islamic Syariah IKNB in Indonesia which is registered in the Otoritas Jasa Keuangan as many as five sectors, while the sample of this study is three Islamic Non-Bank Financial Industry sectors which are available monthly financial statements. The method of data analysis in this study uses multiple linear regression analysis with the SPSS version 18. Based on the results of the test, the data used is normally distributed and meets all the classical assumption test criteria. The results of this study also show that there are negative effects of ROA and BOPO on market share, while ROE has a positive influence on market share. Variable Inflation has no influence on market share. The overall contribution of the independent variable to the dependent variable is Market Share is $67 \%$, while the rest is determined by other variables not examined in this study.
\end{abstract}

Keywords: ROA, ROE, BOPO, Inflation, Market Share, Non-Bank Sharia Financial Industry 


\section{Faktor-faktor yang Mempengaruhi Pangsa Pasar Industri Keuangan Syariah Non-Bank \\ Diharpi Herli Setyowati, Ayu Sartika, Setiawan DOI: 10.24252/iqtisaduna.v5i2.10986}

\section{PENDAHULUAN}

Sektor keuangan yang efektif dan berkembang diakui dalam banyak literatur akademik merupakan hal penting yang mempengaruhi dan menunjang pertumbuhan ekonomi (Faza, 2017). Terlebih sektor keuangan di Indonesia telah ditopang dengan sistem keuangan konvensional dan syariah. Namun, secara agregat, market share industri keuangan syariah di Indonesia baru mencapai 8,55 persen dari total keseluruhan aset di industri jasa keuangan (Republika, 2019). Padahal Indonesia memiliki potensi pertumbuhan yang sangat besar bagi industri keuangan syariah dibanding negara-negara lain di dunia (Setiawan, 2018). Sampai pada awal 2019 data dari Statistik Perbankan Syariah yang dikutip Harian Republika menunjukkan bahwa pasar modal syariah, di luar kapitalisasi saham yang tercatat di Indeks Saham Syariah Indonesia (ISSI), memberikan kontribusi sebesar 55,06 persen atau Rp711,15 triliun lebih tinggi dari aset perbankan syariah yang sebesar Rp479,17 triliun maupun di Industri Keuangan Non Bank (IKNB) syariah yang senilai Rp101,16 triliun sebagai yang terendah.

Untuk terus memacu pertumbuhan industri keuangan syariah ini, pemerintah telah membentuk Komite Nasional Keuangan Syariah (KNKS) melalui penerbitan Peraturan Presiden (Perpres) No. 91 tahun 2016. Dengan terbentuknya KNKS diharapkan Indonesia dapat menjadi penggerak utama perekonomian syariah, tidak hanya menjadi target pasar dan produk industri negara-negara lain. Dukungan berupa peraturan yang dikeluarkan oleh pemerintah tersebut, sejalan dengan landasan Islam yang tertuang dalam surat Al-Baqarah ayat 275:

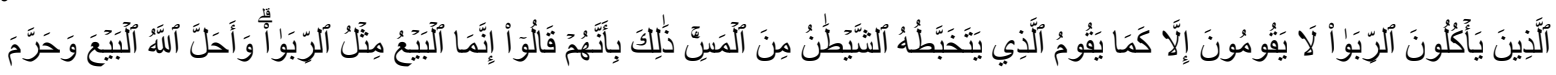

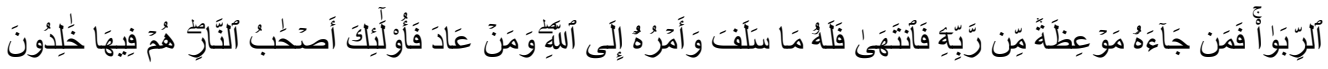

Artinya: "Orang-orang yang makan (mengambil) riba tidak dapat berdiri melainkan seperti berdirinya orang yang kemasukan syaitan lantaran (tekanan) penyakit gila. Keadaan mereka yang demikian itu, adalah disebabkan mereka berkata (berpendapat), sesungguhnya jual beli itu sama dengan riba, padahal Allah telah menghalalkan jual beli dan mengharamkan riba. Orang-orang yang telah sampai kepadanya larangan dari Tuhannya, lalu terus berhenti (dari mengambil riba), maka baginya apa yang telah diambilnya dahulu (sebelum datang larangan); dan urusannya (terserah) kepada Allah. Orang yang kembali (mengambil riba), maka orang itu adalah penghuni-penghuni neraka; mereka kekal di dalamnya."

Ayat tersebut dimaksudkan untuk meninggalkan sistem riba dan kembali pada sistem syariah, karena sesuai dengan kondisi penduduk Indonesia yang mayoritas memeluk agama Islam. Pemerintah akhirnya bekerjasama dengan Majelis Ulama Indonesia untuk mengatur hal-hal yang berkaitan dengan syariah.

Salah satu cara untuk melihat besaran kontribusi yang diberikan tiap industri adalah melalui penguasaan pangsa pasar yang mampu dicapai industri tersebut. Asmoro (2018) 


\section{Faktor-faktor yang Mempengaruhi Pangsa Pasar \\ Industri Keuangan Syariah Non-Bank \\ Diharpi Herli Setyowati, Ayu Sartika, Setiawan \\ DOI: 10.24252/iqtisaduna.v5i2.10986}

mengungkapkan bahwa penguasaan pangsa pasar yang besar akan dimanfaatkan oleh perusahaan-perusahaan untuk semakin menguasai pasar. Assauri (2010) menjelaskan tentang cara pengukuran pangsa pasar melalui jumlah penjualan suatu perusahaan dibandingkan dengan total penjualan seluruh perusahaan dalam industri sejenis, dapat dijadikan sebagi perhitungan pangsa pasar.

Dari hasil penelitian yang telah dilakukan oleh Rahman (2016) disebutkan bahwa variabel NPF, BOPO, CAR, dan SBIS berpengaruh terhadap market share bank syariah. Dalam jangka pendek atau periode awal pengamatan BOPO memiliki pengaruh yang paling dominan. Berbeda dengan Asmoro (2018) yang menggunakan variabel BOPO, ROA, CAR, dan FDR dari hasil penelitiannya variabel BOPO memiliki pengaruh tidak signifikan terhadap Market Share. Selanjutnya Purboastuti, dkk (2015) "Pengaruh Indikator Utama Terhadap Pangsa Pasar Perbankan Syariah", bisa dikatakan bahwa indikator-indikator seperti ROA, NPF, FDR, dan Nisbah secara bersama-sama mempengaruhi pangsa pasar perbankan Islam di Indonesia. Dari ketiga penelitian tersebut ditemukan adanya perbedaan pengaruh variabel BOPO terhadap pangsa pasar perbankan syariah, sedangkan variabel ROA memiliki pengaruh yang signifikan terhadap pangsa pasar perbankan syariah. Dari beberapa variabel tersebut, tidak semua variabel dapat dijadikan sebagai pengujian terhadap pangsa pasar IKNB Syariah. Pada dasarnya, antara industri perbankan dan industry non-bank sama-sama memiliki fungsi penghimpunan dan penyaluran dana. Bagian yang membedakan keduanya adalah sumber perolehan dana dan proses penyaluran dana tersebut.

Industri Keuangan Non-Bank dalam kegiatannya memberikan pelayanan dalam bidang keuangan berupa investasi, pengelolaan resiko, maupun tabungan yang bersifat kontrak (Roadmap IKNB Syariah 2015-2019). Dalam data statistik IKNB Syariah Juli 2018 terdapat beberapa sektor dalam IKNB Syariah, yaitu Asuransi Syariah, Lembaga Pembiayaan Syariah, Lembaga Jasa Keuangan Syariah Khusus, Dana Pensiun, dan Lembaga Keuangan Mikro Syariah. Dari kelima sektor tersebut, asuransi syariah memiliki pangsa pasar paling tinggi. Disusul oleh sektor pembiayaan dan lembaga jasa keuangan syariah khusus, sedangkan dua sektor lain, yakni lembaga keuangan mikro syariah dan dana pensiun masih termasuk sebagai pelaku baru dalam industri ini karena belum terdapat adanya regulasi yang cukup mendukung mengenai kegiatan pada kedua lembaga tersebut.

Faktor-faktor yang mempengaruhi pangsa pasar tidak terlepas dari kondisi internal suatu perusahan itu pula seperti tingkat perputaran aset, tingkat produktivitas, total aset, tingkat profitabilitas dan pengendalian biaya operasional akan mempengaruhi pangsa pasar suatu industri, namun hingga saat ini masih sedikit sekali penelitian yang dilakukan mengenai hal-hal yang dapat mempengaruhi pangsa pasar Industri Keuangan Non-Bank Syariah selain yang dilakukan oleh Otoritas Jasa Keuangan. Beberapa penelitian mengenai pangsa pasar 


\section{Faktor-faktor yang Mempengaruhi Pangsa Pasar \\ Industri Keuangan Syariah Non-Bank \\ Diharpi Herli Setyowati, Ayu Sartika, Setiawan \\ DOI: 10.24252/iqtisaduna.v5i2.10986}

yang telah dilakukan, justru lebih meneliti pangsa pasar perbankan syariah. Untuk itu, penelitian pangsa pasar perbankan syariah bisa dijadikan sebagai acuan agar dapat mengetahui faktor-faktor yang mempengaruhi pangsa pasar Industri Keuangan Non-Bank Syariah. Berdasarkan latar belakang belakang tersebut, dapat dirumuskan masalah yang akan dibahas yaitu untuk mengetahui adanya pengaruh Retun on Assets, Biaya Operasional Pendapatan Operasional, Retun on Equity, dan Inflasi terhadap Pangsa Pasar IKNB Syariah baik secara simultan maupun secara parsial.

\section{TINJAUAN TEORITIK}

\section{Pangsa Pasar}

Pasar muncul karena adanya penawaran dan permintaan sehingga terjadi suatu transaksi dalam pasar. Pangsa Pasar adalah porsi dari penjualan industri atas barang atau jasa yang dikendalikan perusahaan merupakan pengertian pangsa pasar menurut Stiawan (2009). Rahman (2016) menyatakan pasar ditetapkan oleh kondisi permintaan yang mewujudkan daerah pilihan konsumen atas barang. Suatu perusahaan yang menjalankan kegiatan operasinya tentu tidak terlepas dari kondisi pasar yang akan mempengaruhi aktifitas perusahaan tersebut. Baik perusahaan yang bergerak pada bidang jasa, manufaktur, maupun perusahaan dagang akan sangat memperhatikan kondisi pasar yang biasanya dikaitkan dengan kemampuan penguasaan pangsa pasar suatu perusahaan dengan perusahaan lain.

Kriteria pangsa pasar yang sesuai dengan Industri Keuangan Non-Bank Syariah ini sendiri terdiri dari berbagai macam golongan sesuai dengan kondisi perusahaan yang berada dalam industri ini. Seperti yang tercantum dalam Roadmap Industri Keuangan Non-Bank Syariah periode 2015-2019 oleh Otoritas Jasa Keuangan yaitu menyasar masayrakat dengan kebutuhan pembiayaan skala mikro, kecil dan menengah. Dimana dalam statistik Bank Indonesia disampaikan bahwa pembiayaan skala mikro yaitu lebih dari Rp5o ribu hinnga Rp50 juta, pembiayaan skala kecil lebih dari Rp50 juta hingga Rp500 juta, sedangkan pembiayaan menengah lebih dari Rp500 juta hingga Rp5 miliar.

\section{Kinerja Keuangan}

Kinerja keuangan adalah suatu analisis yang dilakukan untuk melihat sejauh mana suatu perusahaan telah melaksanakan keuangannya dengan menggunakan aturan-aturan pelaksanaan keuangan secara baik dan benar merupakan pengertian kinerja keuangan menurut Asmoro (2018). Pengelolaan keuangan yang baik dan efisien, dapat menghasilkan kinerja keuangan yang optimal pula. Sesuai dengan ajaran dalam Islam untuk meninggalkan segala bentuk pemborosan harta yang tertuang dalam surat Al-Israa' ayat 26-27: 
Faktor-faktor yang Mempengaruhi Pangsa Pasar

Industri Keuangan Syariah Non-Bank

Diharpi Herli Setyowati, Ayu Sartika, Setiawan

DOI: 10.24252/iqtisaduna.v5i2.10986

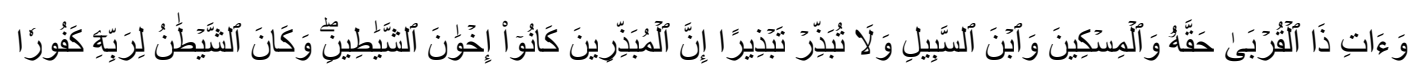

Artinya: "Dan berikanlah kepada keluarga-keluarga yang dekat akan haknya, kepada orang miskin dan orang yang dalam perjalanan dan janganlah kamu menghamburhamburkan (hartamu) secara boros. Sesungguhnya pemboros-pemboros itu adalah saudara-saudara syaitan dan syaitan itu adalah sangat ingkar kepada Tuhannya."

Dalam hal ini, konsep kinerja keuangan yang telah ada tidak selalu digunakan untuk mengukur kualitas kinerja perbankan saja, namun dapat digunakan pula sebagai acuan dalam menganalisis kualitas kinerja industri keuangan non-bank. Dapat disimpulkan dari pernyataan para ahli dan peraturan yang ditetapkan pemerintah maupun Majelis Ulama Indonesia bahwa konsep untuk menilai kinerja keuangan industri keuangan non-bank syariah sama dengan perbankan syariah yang mengadopsi dari sistem perbankan yang telah ada. Kinerja keuangan suatu lembaga dapat diukur dengan analisis rasio keuangan yaitu rasio rentabilitas, rasio likuiditas, rasio aktifitas, dan rasio solvabilitas.

\section{Hipotesis}

Industri keuangan non-bank dapat menjadi salah satu alternatif dalam melakukan investasi maupun memenuhi kebutuhan akan transaksi keuangan sehari-hari. Industri keuangan non-bank memiliki sedikit perbedaan peran dengan industri perbankan, namun tidak menutup kemungkinan bagi industri keuangan non-bank untuk ikut berkontribusi dalam jasa perbankan dan berperan aktif di masyarakat. Hal ini tentunya dapat dilihat melalui posisi pangsa pasar industri keuangan non-bank.

Dalam berbagai berita dan data yang ada selalu menunjukkan bahwa posisi industri keuangan non-bank masih tetap lebih kecil dibandingkan industri perbankan. Stiawan (2009) menyatakan bahwa anilisis pangsa pasar mencerminkan kinerja pemasaran yang dikaitkan dengan posisi persaingan perusahaan dalam suatu industri. Asmoro (2018) menyatakan ROA menggambarkan kemampuan bank dalam menghasilkan profit (laba) melalui penggunaan sejumlah aktiva bank. Masassya (2014:347) dalam bukunya yang berjudul "9o Rahasia Investasi Pribadi" menyatakan walaupun tingkat suku bunga kredit perbankan konvensional tidak terlalu tinggi dengan bunga simpanan kecil, namun memiliki ROA dan ROE tinggi, maka bank tersebut layak dipilih sebagai tempat untuk berinvestasi. Chapra (2000:9) mengungkapkan bahwa secara teori inflasi tidak berpengaruh pada lembaga keuangan.

\section{METODE PENELITIAN}

\section{Pemilihan Sampel dan Data}

Sampel adalah sebagian, atau subset (himpunan bagian), dari suatu populasi (Harinaldi, 2010). Pengambilan sampel dalam penelitian ini menggunakan metode 


\section{Faktor-faktor yang Mempengaruhi Pangsa Pasar \\ Industri Keuangan Syariah Non-Bank \\ Diharpi Herli Setyowati, Ayu Sartika, Setiawan \\ DOI: 10.24252/iqtisaduna.v5i2.10986}

berdasarkan tujuan atau purposive sampling (judgment sampling/snowball sampling). Asnawi dan Wijaya (2005) menyatakan purposive sampling adalah pengambilan data disesuaikan dengan kriteria-kriteria yang telah ditentukan sebelumnya (tujuannnya). Penentuan sampel berdasarkan tujuan mengharuskan bahwa informasi yang didapat tentang variasi antara sub unit sebelum sampel dipilih (Wijaya, 2018). Kriteria-kriteria industri keuangan non-bank syariah yang ditentukan dalam pemilihan sampel penelitian ini sebagai berikut:

1. IKNB Syariah yang terdaftar di Otoritas Jasa Keuangan

2. IKNB Syariah yang memiliki Neraca dan Laporan Laba Rugi bulanan secara berkala yaitu sejak Juli 2015 sampai dengan Juni 2018 pada situs Otoritas Jasa Keuangan

Berdasarkan kriteria tersebut, diperoleh tiga sektor yang memenuhi kriteria yang dapat digunakan sebagai sampel dalam penelitian ini yaitu Asuransi Syariah, Lembaga Pembiayaan Syariah, dan Lembaga Jasa Keuangan Khusus Syariah. Untuk mengetahui pengaruh terhadap pangsa pasar, data yang digunakan variabel pangsa pasar adalah data $n+1$. Jenis data yang digunakan dalam penelitian ini merupakan data kuantitatif. Data yang diambil berupa data laporan keuangan bulanan IKNB Syariah yang diperoleh dari halaman Otoritas Jasa Keuangan (OJK) selama periode Juli 2015 - Juni 2018.

Studi pustaka adalah suatu karangan ilmiah yang berisi pendapat berbagai pakar mengenai suatu masalah, yang kemudian ditelaah, dibandingkan, dan ditarik kesimpulannya (Mulyono dkk, 2000). Studi pustaka yang dilakukan dengan cara pengumpulan data dan teori yang dapat diperoleh melalui berbagai macam referensi seperti arikel, buku, jurnal, dan penelitian terdahulu.

\section{Teknik Analisis Data}

Dalam penelitain ini dilakukan analisis data menggunakan Analisis Regresi Linear Berganda untuk mengetahui pengaruh variabel Independen terhadap variabel Dependen. Alat yang digunakan dalam mengolah dan menganalisis data penelitian ini yaitu SPSS versi 18. Pada penelitian ini, metode analisis data yang digunakan untuk menganalisis data panel adalah Uji Asumsi Klasik, Uji Regresi Berganda dan Uji Koefisien Determinasi, sedangkan untuk pengujian hipotesis dilakukan secara parsial (Uji t) dan pengujian secara simultan (Uji F). Penelitian ini menggunakan model analisis regresi berganda ROA, ROE, BOPO, dan Inflasi terhadap Pangsa Pasar dengan model sebagai berikut:

$$
Y=a+b_{1} x_{1}+b_{2} x_{2}+b_{3} x_{3}+b_{4} x_{4}+e
$$


Keterangan:

$\begin{array}{ll}Y & =\text { Pangsa Pasar } \\ a & =\text { Konstanta } \\ b_{1}-b_{4} & =\text { Koefisien Regresi } \\ X_{1} & =\text { ROA } \\ X_{2} & =\text { ROE } \\ X_{3} & =\text { BOPO } \\ X_{4} & =\text { Inflasi } \\ e & =\text { Standar Error }\end{array}$

\section{HASIL DAN PEMBAHASAN}

\section{Hasil Penelitian}

Sebelum data dianalisis lebih jauh, data yang telah terkumpul diuji secara statistik deskriptif untuk melihat karakteristik sebaran data. Berikut hasil statistik deskriptif yang dapat disajikan dengan bantuan aplikasi SPSS versi 18 .

Tabel 1. Uji Statistik Deskriptif

\begin{tabular}{|c|c|c|c|c|c|c|c|c|c|}
\hline & \multirow{2}{*}{$\mathbf{N}$} & \multirow{2}{*}{ Range } & \multirow{2}{*}{ Minimum } & \multirow{2}{*}{ Maximum } & \multirow{2}{*}{ Sum } & \multicolumn{2}{|c|}{ Mean } & \multirow{2}{*}{$\begin{array}{c}\begin{array}{c}\text { Std. } \\
\text { Deviation }\end{array} \\
\text { Statistic }\end{array}$} & \multirow{2}{*}{$\begin{array}{l}\text { Variance } \\
\text { Statistic }\end{array}$} \\
\hline & & & & & & Statistic & $\begin{array}{l}\text { Std. } \\
\text { Error }\end{array}$ & & \\
\hline $\begin{array}{l}Y \text { (pangsa } \\
\text { pasar) }\end{array}$ & 108 & 9,008 & 3,151 & 12,159 & 708,098 & 6,55646 & 251978 & 2,722557 & 7,412 \\
\hline Xi (ROA) & 108 & 22,244 & ,115 & 22,359 & 447,879 & 4,14703 &, 365240 & 3,795687 & 14,407 \\
\hline X2 (ROE) & 108 & 93,108 & 643 & 93,751 & 3360,046 & 31,11153 & 2,248415 & 23,366219 & 545,980 \\
\hline $\mathrm{X}_{3}$ (BOPO) & 108 & 120,929 & $-32,232$ & 88,696 & 4784,763 & 44,30337 & 3,009319 & 31,273763 & 978,048 \\
\hline X4 (Inflasi) & 108 & ,045 & , 028 & , O73 & 4,427 & ,04099 & ,001199 & ,012460 & ,OOO \\
\hline \multicolumn{10}{|l|}{ Valid N } \\
\hline (listwise) & & & & & & & & & \\
\hline
\end{tabular}

Berdasarkan tabel pada tabel 1 di atas statistik deskriptif dapat dilihat nilai rata-rata Pangsa Pasar adalah 6.556 dengan nilai Pangsa Pasar minimum sebesar 3.151 terjadi pada Asuransi Syariah di bulan Januari 2016 dan nilai Pangsa Pasar maksimum sebesar 12.159 terjadi pada Lembaga Jasa Keuangan Khusus di bulan Oktober 2017. Nilai rata-rata ROA adalah 4.147, nilai minimum ROA sebesar 0.115 terjadi pada Lembaga Jasa Keuangan Khusus di bulan Januari 2018, sedangkan nilai maksimum ROA sebesar 22.359 terjadi pada Asuransi Syariah di bulan Agustus 2017.

Selanjutnya nilai rata-rata ROE adalah 31.111 dan memiliki nilai minimum yang terjadi pada Asuransi Syariah di bulan Januari 2017 yaitu sebesar 0.643 serta nilai maksimum sebesar 93.751 yang terjadi pada Lembaga Pembiayaan Syariah di bulan Desember 2015. Nilai rata-rata BOPO 44.303 dengan nilai minimum sebesar -32.232 pada Lembaga Jasa Keuangan 


\section{Faktor-faktor yang Mempengaruhi Pangsa Pasar \\ Industri Keuangan Syariah Non-Bank \\ Diharpi Herli Setyowati, Ayu Sartika, Setiawan \\ DOI: 10.24252/iqtisaduna.v5i2.10986}

Khusus di Bulan Januari 2018 dan nilai maksimum sebesar 88.696 yang terjadi pada Lembaga Pembiayaan Syariah di bulan September 2015. Variabel terakhir yaitu Inflasi memiliki nilai rata-rata 0.040 dengan nilai minimum 0.028 pada bulan Agustus 2016 serta nilai maksimum sebesar 0.073 pada bulan Juni dan Juli 2015.

\section{Uji Asumsi Klasik}

Untuk melihat model yang dihasilkan oleh analisis regresi linear berganda terbebas dari asumsi klasik, maka diperlukan pengujian lebih lanjut yaitu dengan uji normalitas, uji multikolinearitas, uji autokorelasi, dan uji heteroskedastisitas. Berikut hasil masing-masing pengujian asumsi klasik tersebut.

\section{Gambar 1. Hasil Uji Normalitas}

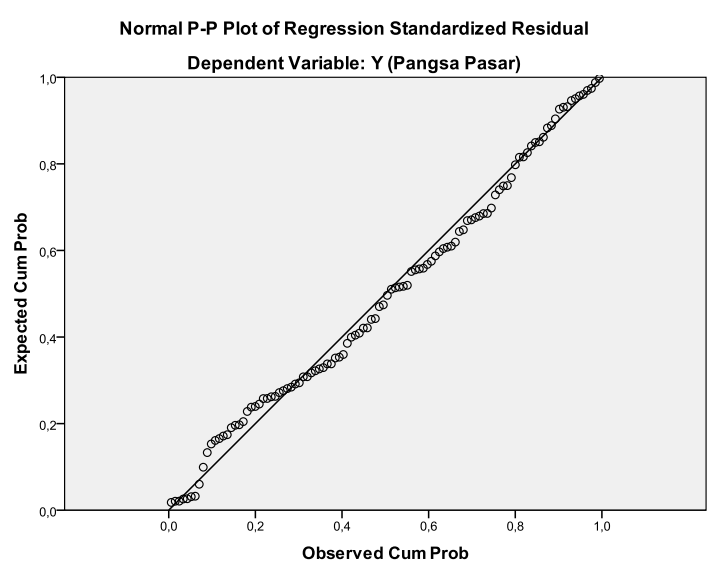

Berdasarkan gambar pada gambar 1 yaitu hasil uji normalitas terlihat bahwa data ploting (titik-titik) mengikuti garis diagonal artinya data yang digunakan pada penelitian ini terdistribusi normal.

Tabel 2. Uji Multikolinearitas

\begin{tabular}{cccc}
\hline \multirow{2}{*}{ Model } & \multicolumn{2}{c}{ Collinearity Statistic } \\
\cline { 2 - 4 } & \multicolumn{2}{c}{ Tolerance } & \multicolumn{2}{c}{ VIF } \\
\hline 1 & (Constant) & & 1,093 \\
\hline X1 (ROA) &, 915 & 1,086 \\
\hline X2 (ROE) &, 920 & 1,077 \\
\hline X3 (BOPO) &, 929 & 1,025 \\
\hline X4 (Inflasi) &, 976 &
\end{tabular}

Dilihat dari tabel hasil uji multikolinieritas pada tabel 2 bahwa nilai tolerance dari masingmasing variabel independen memiliki nilai yang lebih besar dari o.10o dan nilai VIF lebih kecil dari 10.00, sehingga data yang digunakan dalam penelitian ini tidak terdapat masalah multikolinearitas.

Tabel 3. Uji Autokorelasi 
Faktor-faktor yang Mempengaruhi Pangsa Pasar

Industri Keuangan Syariah Non-Bank

Diharpi Herli Setyowati, Ayu Sartika, Setiawan DOI: 10.24252/iqtisaduna.v5i2.10986

\begin{tabular}{ccc}
\hline Model & $\begin{array}{c}\text { Std. Error of the } \\
\text { Estimate }\end{array}$ & $\begin{array}{l}\text { Durbin- } \\
\text { Watson }\end{array}$ \\
\hline dimension & 1,560683 &, 437 \\
\hline
\end{tabular}

Dari tabel hasil uji autokorelasi, dapat diketahui bahwa nilai Durbin-Watson Statistic adalah 0.437. Sesuai dengan kriteria yang dikemukakan oleh Santoso, angka tersebut berada diantara -2 sampai +2, artinya model regresi dalam penelitian ini terbebas dari masalah autokorelasi.

Gambar 2. Hasil Uji Heteroskedastisitas

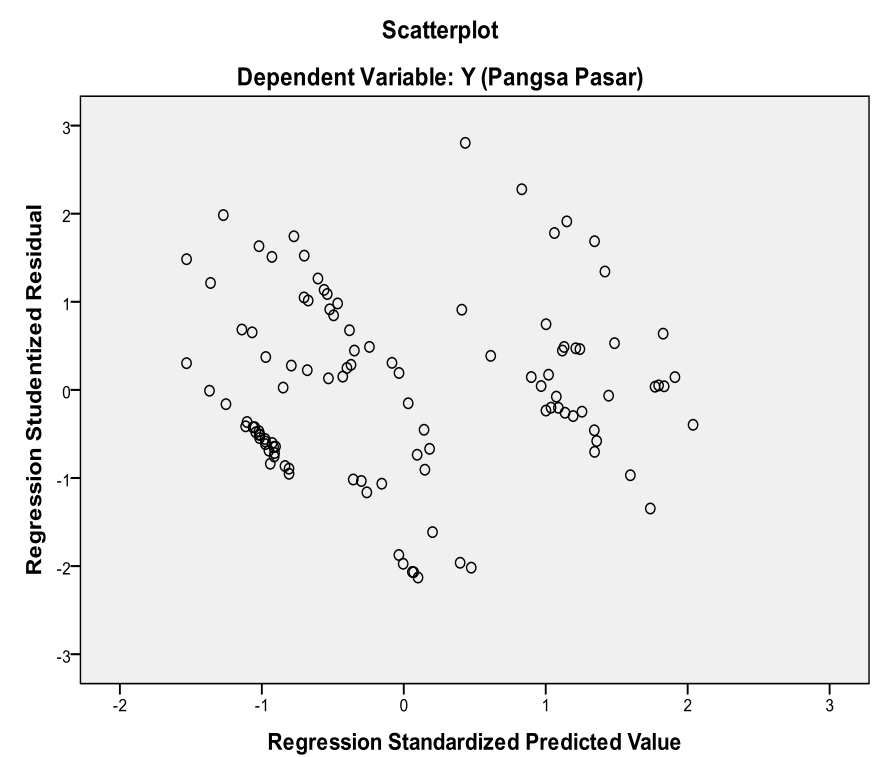

Pada gambar 2 hasil uji heteroskedastisitas, dapat dilihat titik-titik menyebar pada semua area dan tidak membentuk pola tertentu. Persebaran titik berada di atas dan di bawah o sumbu y, artinya data yang digunakan dalam penelitian ini tidak terdapat masalah heteroskedastisitas.

\section{Analisis Regresi Linear Berganda}

Berikutnya dilakukan analisis regresi linear berganda untuk melihat model yang terbentuk pada penelitian ini.

Tabel 4. Uji Regresi Linear Berganda

\begin{tabular}{|c|c|c|c|c|c|c|}
\hline & \multirow[t]{2}{*}{ Model } & \multicolumn{2}{|c|}{$\begin{array}{l}\text { Unstandardized } \\
\text { Coefficients }\end{array}$} & \multirow{2}{*}{$\begin{array}{c}\begin{array}{c}\text { Standardized } \\
\text { Coefficients }\end{array} \\
\text { Beta } \\
\end{array}$} & \multirow[t]{2}{*}{$\mathbf{t}$} & \multirow[t]{2}{*}{ Sig. } \\
\hline & & B & Std. Error & & & \\
\hline \multirow[t]{2}{*}{1} & (Constant) & 7,735 & ,590 & & 13,106 & , 000 \\
\hline & $\mathrm{X} 1$ (ROA) &,- 226 & , 042 &,- 315 & $-5,433$ & ,ooo \\
\hline
\end{tabular}


Faktor-faktor yang Mempengaruhi Pangsa Pasar

Industri Keuangan Syariah Non-Bank

Diharpi Herli Setyowati, Ayu Sartika, Setiawan

DOI: 10.24252/iqtisaduna.v5i2.10986

\begin{tabular}{|c|c|c|c|c|c|}
\hline \multirow[t]{2}{*}{ Model } & \multicolumn{2}{|c|}{$\begin{array}{l}\text { Unstandardized } \\
\text { Coefficients }\end{array}$} & \multirow{2}{*}{$\begin{array}{c}\begin{array}{c}\text { Standardized } \\
\text { Coefficients }\end{array} \\
\text { Beta }\end{array}$} & \multirow[t]{2}{*}{$\mathbf{t}$} & \multirow[t]{2}{*}{ Sig. } \\
\hline & B & Std. Error & & & \\
\hline X2 (ROE) & , o57 & ,007 & ,492 & 8,525 & , ooo \\
\hline $\mathrm{X}_{3}$ (BOPO) &,- 066 & ,005 &,- 760 & $-13,209$ & ,ooo \\
\hline $\mathrm{X}_{4}$ (Inflasi) & 22,001 & 12,259 & 101 & 1,795 & , 076 \\
\hline
\end{tabular}

Berdasarkan hasil pengujian pada tabel 4 di atas maka dapat dibentuk model persamaan sebagai berikut:

Pangsa Pasar $=7.735-0.226 R O A+0.057 R O E-0.066 B O P O+22.001$ Inflasi $+e$

\section{Uji Hipotesis}

Berdasarkan tabel hasil uji F pada tabel 5 di bawah ini, menunjukkan nilai probabilitas yang lebih kecil dari 0.05 yaitu 0.000, artinya variabel independen yaitu ROA, ROE, BOPO, dan Inflasi secara bersama-sama berpengaruh secara signifikan terhadap variabel dependen yaitu Pangsa Pasar.

Tabel 5. Uji F

\begin{tabular}{rlrrrrr}
\hline Model & $\begin{array}{r}\text { Sum of } \\
\text { Square }\end{array}$ & df & $\begin{array}{c}\text { Mean } \\
\text { Square }\end{array}$ & F & Sig. \\
\hline 1 & Regression & 542,238 & 4 & 135,559 & 55,654 & , $^{\text {ooo }}$ \\
\hline Residual & 250,880 & 103 & 2,436 & & \\
\hline Total & 793,118 & 107 & & & \\
\hline
\end{tabular}

Sedangkan untuk uji t dapat dilihat pada tabel 4 di atas. Nilai probabilitas yang diperoleh dari variabel ROA dalam penelitian ini sebesar 0.00o lebih kecil dari 0.05 dan berada di daerah yang berpengaruh negatif, maka $\mathrm{H}_{1.0}$ diterima dan $\mathrm{H}_{1.1}$ ditolak. Dimana, variabel ROA memiliki pengaruh negatif terhadap pangsa pasar. Nilai probabilitas yang diperoleh dari variabel ROE dalam penelitian ini sebesar sebesar 0.0oo lebih kecil dari 0.05 dan berada di daerah yang berpengaruh positif, maka $\mathrm{H}_{2.0}$ diterima dan $\mathrm{H}_{2.1}$ ditolak. Dimana, variabel ROE memiliki pengaruh positif terhadap pangsa pasar. Nilai probabilitas yang diperoleh dari variabel BOPO dalam penelitian ini sebesar sebesar 0.00o lebih kecil dari 0.05 dan berada di daerah yang berpengaruh negatif, maka $\mathrm{H}_{3.0}$ diterima dan $\mathrm{H}_{3.1}$ ditolak. Dimana, variabel ROA memiliki pengaruh negatif terhadap pangsa pasar. Nilai probabilitas yang diperoleh dari variabel Inflasi dalam penelitian ini sebesar 0.76 lebih besar dari dari 0.05 dan berada di daerah yang tidak berpengaruh positif, maka $\mathrm{H}_{4.0}$ ditolak dan $\mathrm{H}_{4.1}$ diterima. Dimana, variabel Inflasi tidak memiliki pengaruh terhadap pangsa pasar. 


\section{Faktor-faktor yang Mempengaruhi Pangsa Pasar Industri Keuangan Syariah Non-Bank \\ Diharpi Herli Setyowati, Ayu Sartika, Setiawan DOI: 10.24252/iqtisaduna.v5i2.10986}

\section{Pembahasan}

Dapat dilihat dari gambar 3 grafik pangsa pasar IKNB Syariah di bawah menunjukkan bahwa pada sektor Asuransi Syariah sempat mengalami penurunan pangsa pasar yang signifikan di akhir tahun 2015 kemudian stabil hingga akhir Juni 2018, sedangkan pada Lembaga Pembiayaan Syariah mengalami perubahan yang fluktuatif sepanjang periode penelitian.

Gambar 3. Grafik Pangsa Pasar IKNB Syariah Juli 2015-Juni 2018

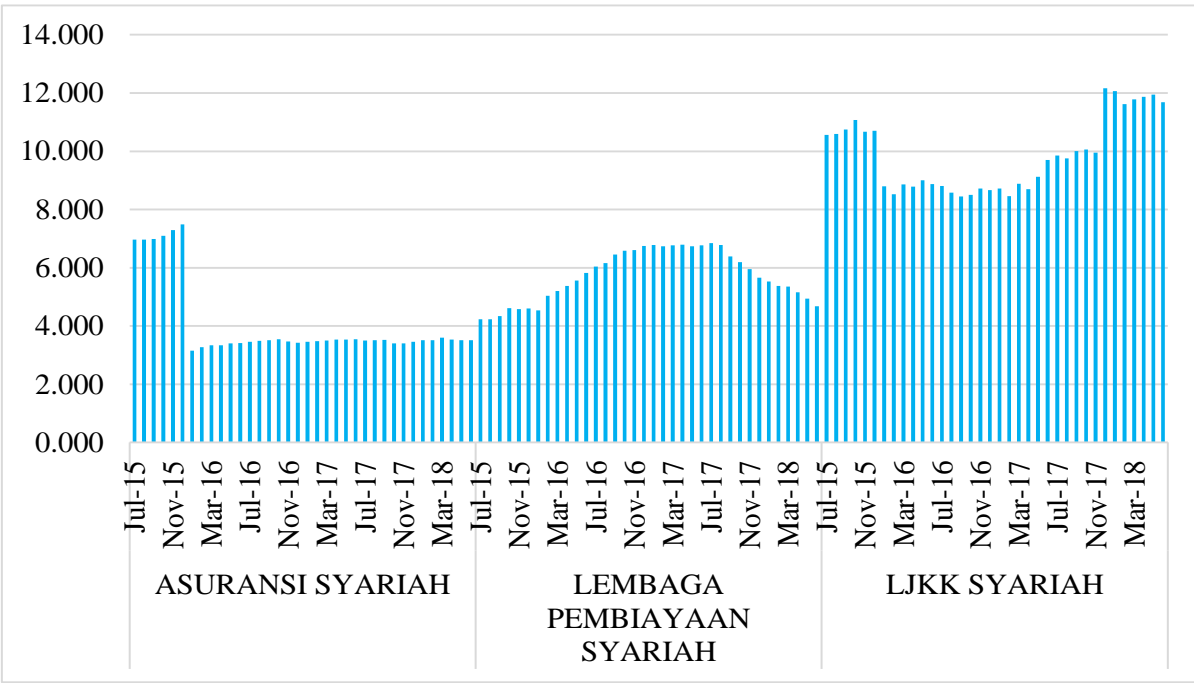

Pada Lembaga Jasa Keuangan Khusus Syariah (LJKK) terlihat pangsa pasarnya jauh lebih tinggi dan berfluktuasi dibandingkan Asuransi Syariah maupun Lembaga Pembiayaan Syariah. Hal ini disebabkan karena perbedaan jumlah pemain yang ada di ketiga sektor IKNB Syariah tersebut, dimana jumlah pemain di sektor LJKK jauh lebih sedikit dibandingkan pada sektor Asuransi Syariah maupun Lembaga Pembiayaan Syariah. Jumlah pemain di sektor Asuransi yang lebih banyak, membuat persaingan menjadi lebih ketat, namun asuransi syariah telah menunjukkan hasil yang cukup baik dengan kondisi pangsa pasarnya yang cukup stabil. Dapat dikatakan pula bahwa masyarakat lebih tertarik untuk mempercayakan dananya di LJKK Syariah.

\section{Pengaruh ROA, ROE, BOPO, dan Inflasi secara Simultan terhadap Pangsa Pasar}

Sesuai dengan hasil pengolahan data yang dilakukan dalam penelitian ini, hasil uji simultan menunjukkan bahwa keempat variabel independen yaitu ROA, ROE, BOPO, dan Inflasi memiliki pengaruh secara bersama-sama terhadap variabel dependen yaitu Pangsa Pasar. Hal ini dibuktikan dengan nilai signifikansi yang lebih kecil dari $0.05(0.000<0.05)$ berdasarkan uji F. ROA menunjukkan tingkat efisiensi perusahaan dalam mengelola aset yang dimiliki guna memperoleh laba optimal. Apabila ROA suatu perusahaan memiliki 


\section{Faktor-faktor yang Mempengaruhi Pangsa Pasar \\ Industri Keuangan Syariah Non-Bank \\ Diharpi Herli Setyowati, Ayu Sartika, Setiawan \\ DOI: 10.24252/iqtisaduna.v5i2.10986}

peningkatan yang signifikan, maka dapat menggambarkan kinerja perusahaan yang baik, sehingga semakin tinggi pula pangsa pasarnya. Variabel ROE merupakan bagian dari rasio profitabilitas dimana jika nilai ROE semakin tinggi, maka semakin tinggi pula posisi pangsa pasar yang dapat dicapai suatu perusahaan. Pertumbuhan pangsa pasar yang meningkat akibat tingginya nilai ROE, tidak terlepas dari kinerja yang baik untuk memperoleh laba optimal, sehingga dapat mendukung kenaikan pangsa pasar. Nilai BOPO menggambarkan efisiensi kinerja perusahaan dalam mengendalikan biaya operasionalnya terhadap pendapatan operasional. Artinya, semakin kecil nilai BOPO, maka semakin besar kesempatan perusahaan untuk meningkatkan pertumbuhan pangsa pasarnya. Perubahan angka Inflasi yang cenderung stabil juga dapat mempengaruhi nilai pangsa pasar suatu perusahaan ketika didukung dengan perubahan pada variabel lainnya yaitu ROA, ROE, dan BOPO. Dapat dikatakan bahwa kenaikan dan penurunan angka Inflasi diikuti dengan kenaikan atau penurunan posisi pangsa pasar perusahaan.

\section{Pengaruh ROA terhadap Pangsa Pasar}

ROA digunakan untuk mengukur efektifitas perusahaan dalam menghasilkan keuntungan dengan memanfaatkan aktiva yang dimilikinya. Jika ROA suatu perusahaan semakin besar, artinya semakin besar keuntungan yang diperoleh, sehingga dapat menunjukkan bahwa perusahaan mampu mengelola asetnya dengan baik. Umumnya, apabila profitabilitas suatu perusahaan mengalami peningkatan, maka dapat menggambarkan kinerja perusahaan yang baik dan mampu meningkatkan posisi pangsa pasarnya.

Gambar 4. Grafik Pangsa Pasar dan ROA IKNB Syariah Juli 2015-Juni 2018

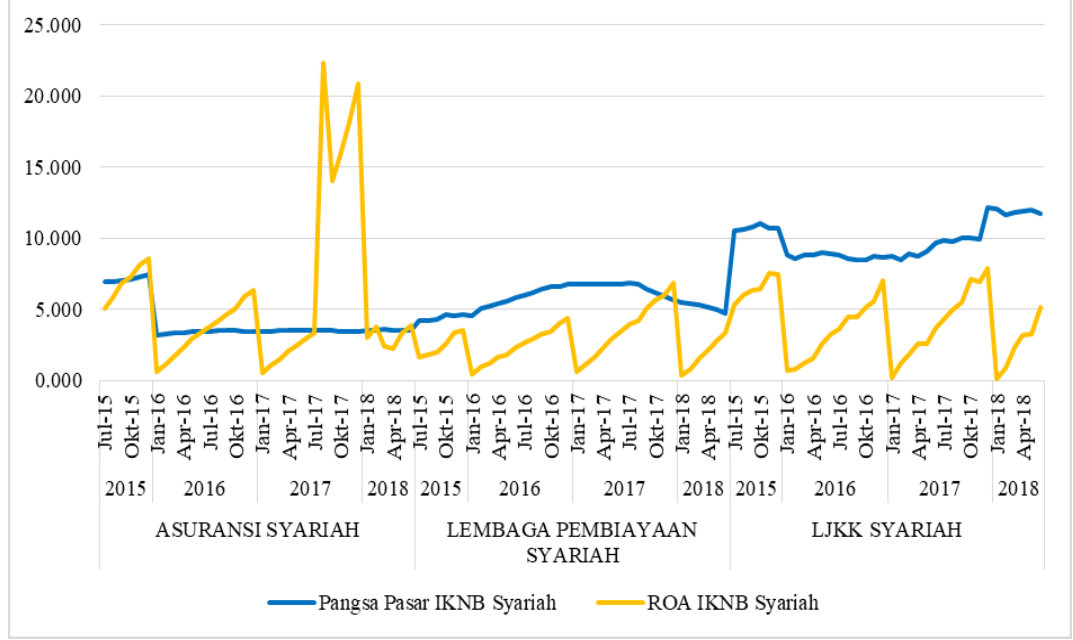

Dapat dilihat pada gambar 4 grafik pangsa pasar dan roa IKNB Syariah, pangsa pasar Lembaga Pembiayaan Syariah menurun di bulan April 2018, namun ROA mengalami kenaikan. Hal yang sama terjadi pada pangsa pasar LJKK Syariah yang mengalami kenaikan, 


\section{Faktor-faktor yang Mempengaruhi Pangsa Pasar \\ Industri Keuangan Syariah Non-Bank \\ Diharpi Herli Setyowati, Ayu Sartika, Setiawan \\ DOI: 10.24252/iqtisaduna.v5i2.10986}

sedangkan ROA terus mengalami penurunan signifikan. Dari hasil pengolahan data dalam penelitian ini, menunjukkan bahwa ROA memiliki pengaruh negatif terhadap pangsa pasar IKNB Syariah. Hal ini dapat diartikan bahwa kenaikan ROA diikuti dengan penurunan pangsa pasar. Hasil ini berbeda dengan penelitian sebelumnya yang dilakukan oleh Purboastuti (2015) dan Asmoro (2018) dimana ROA berpengaruh positif terhadap pangsa pasar.

Perusahaan yang memiliki nilai ROA positif, dapat diartikan bahwa perusahaan tersebut mampu mengelola aktiva secara efisien untuk menghasilkan laba. Sebaliknya, perusahaan yang memiliki nilai ROA negatif menunjukkan perusahaan tidak mampu mengelola aktiva secara efisien yang berakibat perusahaan akan mengalami kerugian. Dalam hal ini, kenaikan total aset perusahaan tidak diimbangi dengan kenaikan laba yang signifikan. Dengan kata lain, terjadi pemborosan dalam perusahaan ketika seharusnya total aktiva yang dimiliki dapat dikelola dengan baik, sehingga kenaikan profitabilitas diikuti dengan peningkatan posisi pangsa pasar perusahaan. Dengan demikian, jika suatu perusahaan mempunyai ROA yang tinggi, maka perusahaan tersebut berpeluang besar dalam meningkatkan pertumbuhan pangsa pasarnya.

Dalam kondisi lain, jika total aktiva yang digunakan perusahaan tidak dikelola dengan baik, maka perusahaan berpotensi mengalami kerugian yang dapat menghambat pertumbuhan perusahaan tersebut. Hal ini terjadi pada IKNB Syariah dimana ROA menunjukkan pengaruh negatif terhadap pangsa pasar yang dapat mengindikasikan adanya kerugian, namun kondisi tersebut tidak menghambat usaha IKNB Syariah untuk meningkatkan laju pertumbuhannya. Sebaliknya, ketika ROA IKNB Syariah mengalami peningkatan yang diikuti dengan penuruan pangsa pasar, menunjukkan perusahaan masih belum mampu mengelola aktivanya dengan baik untuk menghasilkan laba yang optimal dan menghambat pertumbuhan pangsa pasarnya.

\section{Pengaruh ROE terhadap Pangsa Pasar}

ROE mencerminkan tingkat perolehan pendapatan atas suatu investasi dalam bentuk modal sendiri. Perusahaan yang memiliki nilai ROE tinggi, tentu akan diikuti dengan tingginya kesempatan suatu perusahaan tersebut untuk meningkatkan pangsa pasarnya. ROE yang tinggi juga dapat menunjukkan efisiensi perusahaan atas pengelolaan modalnya untuk memperoleh laba optimal bagi perusahaan, sehingga hasil ini dapat diikuti pula dengan semakin meningkatnya pertumbuhan pangsa pasar perusahaan tersebut. 
Gambar 5. Grafik Pangsa Pasar dan ROE IKNB Syariah Juli 2015-Juni 2018

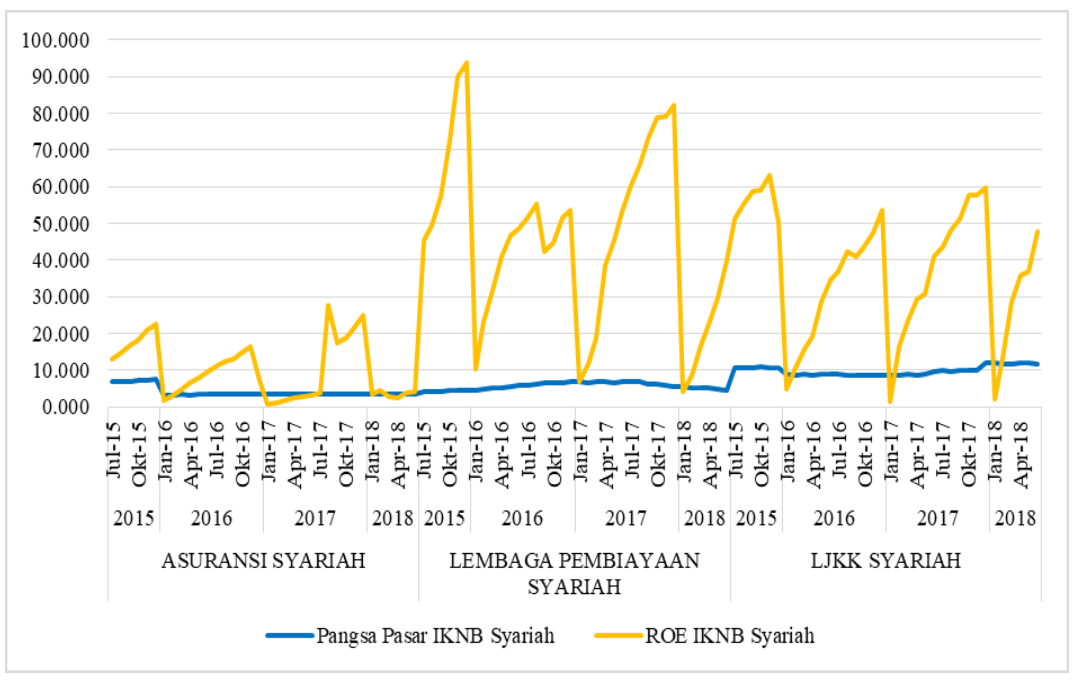

Dari gambar grafik pangsa pasar dan ROE IKNB Syariah pada gambar 5 di atas mununjukkan bahwa ROE sektor Asuransi Syariah di bulan Januari 2016 mengalami penurunan yang diikuti dengan turunnya pangsa pasar sektor tersebut. Hal ini juga terjadi pada sektor Lembaga Pembiayaan Syariah, dimana pada sekitar bulan April 2018 hingga Juni 2018 nilai ROE pada sektor tersebut mengalami kenaikan dan diikuti nilai pangsa pasarnya yang juga mengalami kenaikan. Dari hasil olah data yang dilakukan dalam penelitian ini, menunjukkan adanya pengaruh positif ROE terhadap pangsa pasar IKNB Syariah. Dengan demikian, dapat diartikan bahwa kenaikan ROE diikuti pula dengan kenaikan pangsa pasar IKNB Syariah.

Nilai ROE yang tinggi mengindikasikan bahwa perusahaan memiliki kinerja yang baik dan efisien untuk mengelola modal yang dimiliki, sehingga perusahaan mampu memperoleh laba yang optimal diikuti dengan peningkatan pangsa pasarnya. Dampak positif ROE terhadap pangsa pasar dapat dilihat melalui peningkatan pendapatan atau laba yang seimbang dengan jumlah modal yang ditambahkan. Ketika penambahan sejumlah modal yang dilakukan perusahaan tidak diikuti dengan pengelolaan modal yang efisien, tentu hal ini hanya akan mengurangi laba yang diperoleh perusahaan, sehingga pertumbuhan pangsa pasar perusahaan juga akan terhambat.

\section{Pengaruh BOPO terhadap Pangsa Pasar}

Rasio biaya operasional terhadap pendapatan operasional (BOPO) digunakan untuk mengukur kemampuan suatu perusahaan dalam mengendalikan biaya operasional yang dikeluarkannya terhadap pendapatan operasional yang diperoleh. Upaya pengendalian biaya operasional tentu akan menimbulkan peningkatan hasil usaha jika berjalan dengan baik dan 


\section{Faktor-faktor yang Mempengaruhi Pangsa Pasar \\ Industri Keuangan Syariah Non-Bank \\ Diharpi Herli Setyowati, Ayu Sartika, Setiawan \\ DOI: 10.24252/iqtisaduna.v5i2.10986}

sebaliknya. Suatu perusahaan yang berhasil menekan biaya operasional yang dikeluarkan, dapat menggambarkan bahwa kinerja internal perusahaan tersebut berjalan dengan baik. Hal ini dapat menunjukkan jumlah pendapatan yang diperoleh perusahaan masih berada pada angka yang tinggi bahkan setelah dikurangi sedikit biaya operasional. Dengan tingginya nilai pendapatan, maka perusahaan mampu memperoleh laba yang optimal dan dapat mendukung peningkatan pangsa pasar perusahaan tersebut.

Gambar 6. Grafik Pangsa Pasar dan BOPO IKNB Syariah Juli 2015-Juni 2018

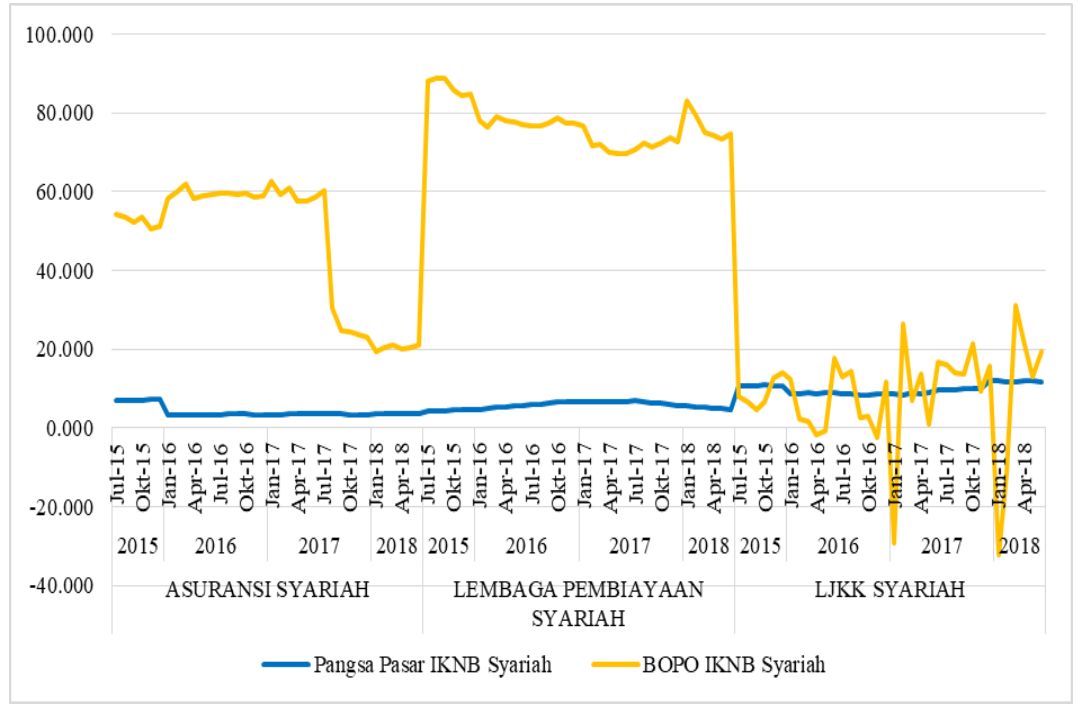

Dalam penelitian ini menunjukkan hasil bahwa BOPO memiliki pengaruh negatif terhadap pangsa pasar IKNB Syariah. Artinya, semakin kecil nilai BOPO, maka semakin besar pangsa pasar suatu perusahaan. Hal ini dapat dilihat pada gambar 6 grafik pangsa pasar dan BOPO IKNB Syariah, nilai BOPO sektor LJKK Syariah di bulan Juli 2015 mengalami penurunan yang siginifikan diikuti dengan kenaikan pangsa pasarnya. Kemudian pada bulan November 2015 hingga Desember 2015 terjadi kenaikan nilai BOPO yang menyebabkan turunnya pangsa pasar LJKK Syariah. Di bulan Januari 2018 terjadi penurunan BOPO hingga mencapai nilai minus, namun pangsa pasar LJKK Syariah justru mengalami kenaikan. Hasil ini sejalan dengan beberapa penelitian sebelumnya yang dilakukan oleh Rahman (2016) dan Asmoro (2018) dimana BOPO memiliki pengaruh terhadap pangsa pasar.

Dari hasil tersebut, dapat dikatakan bahwa IKNB Syariah mampu meningkatkan pangsa pasarnya ketika biaya operasional dikendalikan dengan baik, sehingga pendapatan yang diperoleh tidak mengalami pengurangan yang cukup besar. Pada saat perusahaan mengalami penambahan pendapatan dengan nilai biaya operasional tetap, maka nilai BOPO akan menurun yang menunjukkan kinerja perusahaan berjalan dengan baik dan sebaliknya. Begitupun saat perusahaan mengalami kenaikan pendapatan yang diikuti pula dengan kenaikan biaya operasional, maka nilai BOPO akan meningkat yang menunjukkan kinerja 


\section{Faktor-faktor yang Mempengaruhi Pangsa Pasar \\ Industri Keuangan Syariah Non-Bank \\ Diharpi Herli Setyowati, Ayu Sartika, Setiawan \\ DOI: 10.24252/iqtisaduna.v5i2.10986}

perusahaan tidak cukup baik dan sebaliknya. Dengan demikian, semakin kecil nilai BOPO tentu akan menggambarkan bahwa kinerja suatu perusahaan juga semakin baik, sehingga mempengaruhi pertumbuhan pangsa pasarnya yang akan semakin meningkat.

\section{Pengaruh Inflasi terhadap Pangsa Pasar}

Inflasi menunjukkan adanya kondisi kenaikan harga-harga suatu barang secara bersama-sama dalam periode tertentu. Dimana kenaikan harga barang tersebut tidak harus selalu menunjukkan presentase yang sama di setiap periode. Pada fase terjadinya inflasi akan mengakibatkan penurunan daya beli terhadap mata uang, sehingga dibutuhkan uang dalam jumlah lebih banyak untuk memenuhi kebutuhan konsumsi barang yang sama. Dalam kondisi ini, biasanya masyarakat akan melakukan penarikan dana simpanan atau investasi syariah untuk memenuhi kebutuhannya. Hal ini diikuti dengan langkah dari lembaga keuangan syariah yang akan menaikkan Nisbah Bagi Hasil sebagai upaya untuk mengatasi penarikan dana berlebih oleh masyarakat. Pada saat nilai inflasi menunjukkan angka yang cukup tinggi, tentu hal ini akan membuat masyarakat kehilangan semangat untuk menyimpan dana dan sebaliknya. Kondisi ini menyebabkan lembaga keuangan syariah akan kehilangan sejumlah sumber dana yang dapat menghambat kegiatan opersionalnya yang diikuti dengan penurunan posisi pangsa pasarnya.

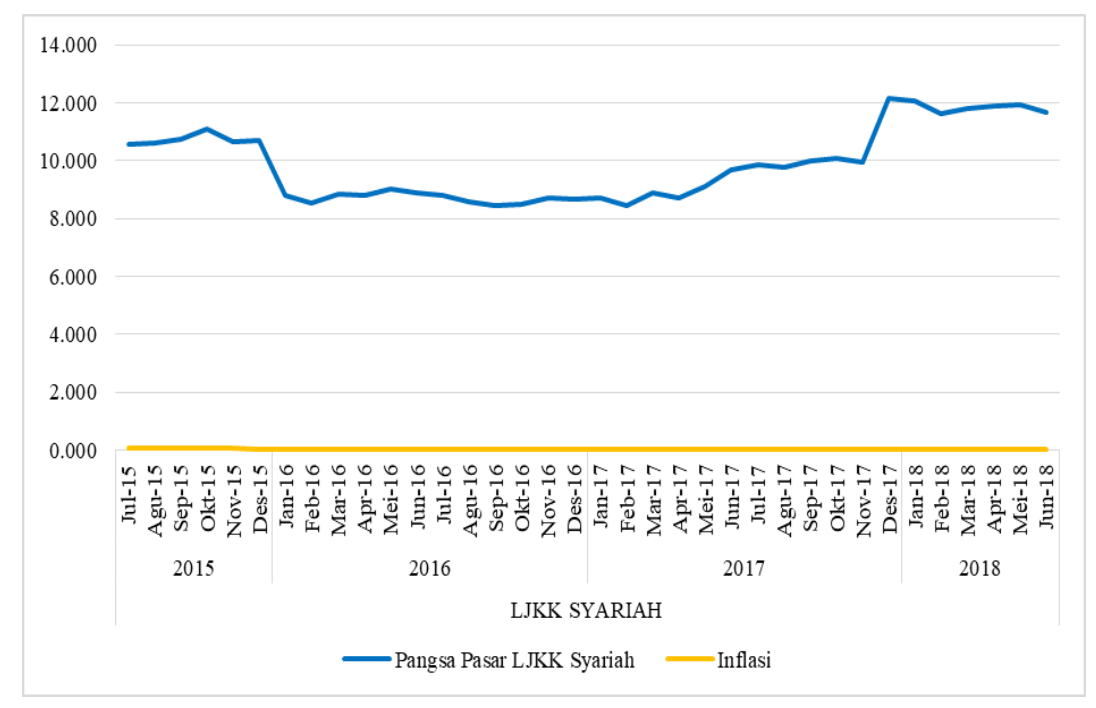

Gambar 7. Grafik Inflasi dan Pangsa Pasar Asuransi Syariah Juli 2015-Juni 2018

Gambar grafik inflasi dan pangsa pasar asuransi pada gambar 7 di atas menunjukkan bahwa angka inflasi selama periode penelitian mengalami kenaikan dan penurunan yang 


\section{Faktor-faktor yang Mempengaruhi Pangsa Pasar \\ Industri Keuangan Syariah Non-Bank \\ Diharpi Herli Setyowati, Ayu Sartika, Setiawan \\ DOI: 10.24252/iqtisaduna.v5i2.10986}

cukup stabil. Meski sempat terjadi penurunan yang cukup signifikan pada akhir tahun 2015 dan kemudian kembali naik pada awal tahun 2016. Dalam penelitian ini, diperoleh hasil bahwa variabel inflasi tidak memiliki pengaruh terhadap pangsa pasar IKNB Syariah. Hal ini menunjukkan bahwa setiap kenaikan atau penurunan angka Inflasi tidak akan diikuti dengan kenaikan atau penuruan pangsa pasar. Hasil penelitian ini sejalan dengan penelitian sebelumnya yang dilakukan oleh Stiawan (2009) serta Muliawati dan Maryati (2015).

Secara kajian teori, hasil penelitian ini yang menunjukkan tidak adanya pengaruh Inflasi terhadap pangsa pasar IKNB Syariah cenderung sesuai dengan teori ekonomi islam murni yang menjelaskan bahwa inflasi tidak menjadi penghambat dalam kegiatan perekonomian syariah. Dalam hal ini, sistem syariah lebih mengutamakan perputaran uang pada sektor riil atau investasi untuk kegiatan produktif, sehingga kondisi naik turunnya inflasi tidak akan mempengaruhi usaha yang dijalankan dan tidak menghambat atau mempercepat pertumbuhan pangsa pasarnya.

\section{KESIMPULAN}

Berdasarkan hasil dan pembahasan penelitian yang dilakukan, dapat dibuat kesimpulkan bahwa ROA, ROE, BOPO, dan Inflasi secara simultan memiliki pengaruh signifikan terhadap pangsa pasar IKNB Syariah. Perubahan yang terjadi pada ROA, ROE, BOPO, dan Inflasi dapat mempengaruhi perubahan pada pangsa pasar. ROA berpengaruh negatif terhadap pangsa pasar IKNB Syariah. Pengaruh yang dimiliki ROA sebesar 0.226\% artinya setiap kenaikan ROA sebesar 1\% maka akan mempengaruhi penurunan pangsa pasar sebesar 0.226\%. Semakin tinggi ROA, maka akan semakin rendah pangsa pasar begitupun sebaliknya. ROE berpengaruh positif terhadap pangsa pasar IKNB Syariah. Pengaruh ROE sebesar 0.057\% artinya setiap kenaikan ROE sebesar 1\% maka akan mempengaruhi kenaikan pangsa pasar sebesar 0.057\%. Semakin tinggi ROE, maka akan semakin tinggi pula pangsa pasar. BOPO berpengaruh negatif terhadap pangsa pasar IKNB Syariah. Pengaruh yang dimiliki BOPO sebesar 0.066\% artinya setiap penurunan BOPO sebesar 1\% maka akan mempengaruhi kenaikan pangsa pasar sebesar 0.066\%. Semakin tinggi BOPO, maka akan semakin rendah pangsa pasar begitupun sebaliknya. Inflasi tidak berpengaruh terhadap pangsa pasar IKNB Syariah. Meskipun nilai Inflasi cukup fluktuatif selama rentang periode data penelitian, namun tidak menunjukkan adanya pengaruh pada pangsa pasar.

\section{DAFTAR PUSTAKA}

Asmoro, W. P. (2018). Analisis Faktor-Faktor yang Mempengaruhi Market Share Bank Syariah di Indonesia. Skripsi, Universitas Islam Negeri Syarif Hidayatullah Jakarta, Jakarta. 


$$
\begin{gathered}
\text { Faktor-faktor yang Mempengaruhi Pangsa Pasar } \\
\text { Industri Keuangan Syariah Non-Bank } \\
\text { Diharpi Herli Setyowati, Ayu Sartika, Setiawan } \\
\text { DOI: 10.24252/iqtisaduna.v5i2.10986 }
\end{gathered}
$$

Asnawi, S. K., \& Wijaya, C. (2005). Riset Keuangan: pengujian-Pengujian Empiris. Jakarta: PT Gramedia Pustaka Utama.

Assauri, S. (2010). Manajemen Pemasaran. Jakarta: Rajawali Pers.

Chapra, M. U. (2000). Sistem Moneter Islam. Jakarta: Gema Insani Pers.

Faza, N. I. (2017). Analisis Kontribusi Industri Keuangan Non-Bank (IKNB) Konvensional dan Industri Keuangan Non-Bank (IKNB) Syariah Terhadap Pertumbuhan Ekonomi Indonesia Tahun 2014-2017. Skripsi, Universitas Islam Negeri Sunan Kalijaga, Yogyakarta.

Harinaldi. (2010). Prinsip-Prinsip Statistik. Jakarta: Erlangga.

Masassya, E. G. (2014). Rahasia Investasi Pribadi. Jakarta: Elex Media Komputindo.

Muliawati, N. L., \& Maryati, T. (2015). Analisis Pengaruh Inflasi, Kurs, Suku Bunga dan Bagi Hasil terhadap Deposito pada PT Bank Syariah Mandiri 2007-2012. Seminar Nasional Cendekiawan 2015.

Purboastuti, N., Anwar, N., \& Suryahani, I. (2015). Pengaruh Indikator Utama Perbankan Terhadap Pangsa Pasar Perbankan Syariah. Journal of Economic and Policy, 8(1), 1322.

Rahman, A. (2016). Analisis Faktor-Faktor yang Mempengaruhi Market Share Bank Syariah. Analytica Islamica, 5(2), 291-314.

Rofiatun, N. F. (2016). Pengaruh Pangsa Pasar dan Indikator Perbankan terhadap Profitabilitas Bank Umum Syariah Indonesia. Journal of Islamic Economics Lariba, 2(1), 13-24.

Stiawan, A. (2009). Analisis Pengaruh Faktor Makroekonomi, Pangsa Pasar dan Karakteristik Bank Terhadap Profitabilitas Bank Syariah. Tesis, Universitas Diponegoro, Semarang.

Ulum, F. (2017). Progresifitas Regulasi Keuangan Syariah di Indonesia. Jurnal Hukum dan Perundangan Islam, 7(2), 422.

Usanti, T. P., \& Shomad, A. (2017). Hukum Perbankan. Jakarta: Kencana.

Wijaya, H. (2018). Analisis Data Kuantitatif Ilmu Pendidikan Teologi. Makassar: Sekolah Tinggi Theologia Jaffray. 